\title{
Status of Multimedia Course ware Design Analysis in Vocational Colleges and Course ware Analysis Review
}

\author{
Liang Yahong \\ Graduate School of Jilin Agricultural University \\ China \\ 1074617240@qq.com
}

\author{
Liu Lianshun* \\ College of Humanities of Jilin Agricultural University \\ China \\ 617063574@qq.com
}

\author{
Wang Yun \\ Graduate School of Jilin Agricultural University \\ China \\ wangyun90@126.com
}

\begin{abstract}
This paper focuses on the understanding of the current situation and the related countermeasures of multimedia course ware design in Higher Vocational Colleges, in order to put forward innovative ideas in this research field. The paper finds out the status of the research on the design and production of the multimedia course ware in the literature by summarizing the views of some domestic and foreign scholars. There is a lot of research space in the comprehensive utilization of the current situation and countermeasures, which contains the professional image, audio and video clips software and traditional software.
\end{abstract}

Keywords—-multimedia course ware; higher vocational colleges; status and countrmeasures

\section{FOREIGN RESEARCH REVIEW}

Since 2015, the multimedia course ware for research mainly focused on better improvement of the efficiency of multimedia design ${ }^{[1]}$ and development of teacher independence creative course ware ${ }^{[2]}$ as well as ethical and legal aspects of multimedia course ware using security and other issues ${ }^{[3]}$,like as For Effective Use of Multimedia in Education, Teachers Must Develop Their Own Educational Multimedia Applications published by Babiker, Mohd. Elmagzoub A.; Using TimeCompression to Make Multimedia Learning More Efficient: Current Research and Practice published by Pastore, Raymond and Ritzhaupt, Albert D; Keeping Kids Safe from a Design Perspective: Ethical and Legal Guidelines for Designing a Video-Based App for Children published by Zydney, Janet Mannheimer and Hooper, Simon. These papers indicate that the researchers of multimedia course ware itself have shifted from cultural environment background.

Prior to 2015, most of the research papers from the following aspects:
A. From the perspective of interactive multimedia of students learning the target planning ${ }^{[4]}$ and application in specific fields are discussed [5] that having a more flexible and interactive multimedia course ware, content more vivid ,more in line with students' needs and so on.

Such as Development of Interactive Multimedia course ware (e-CRAFT) for Craft Education published by Osman, Salyani; Sahari, Noraidah and Zin; Learning "Goal Programming" Using an Interactive Multimedia course ware: Design Factors and Students' Preferences published by Shiong, Kok Boon; Aris, Baharuddin; Ahmad, Maizah Hura; Bilal Ali, Mohamad; Harun, Jamalludin and Tasir.

\section{B. From the using tools to precede research multimedia course ware design and production}

We started studying multimedia courseware design and production from the use of tools, some from the Flash software development to design of multimedia courseware, found that the design of courseware and content network because binding vivid detail and so more in line with the needs of students ${ }^{[6]}$ For reducing the burden on students, improving the classroom efficiency and other affect the results, some researchers explore the multimedia course ware from the $3 \mathrm{D}$ software color management ${ }^{[7]}$.

\section{From the aspects of education theory}

Such as constructivism theory explains the multimedia course ware in English ESP(English for Specific Purpose)teaching with more international, more flexible features to achieve better learning outcomes ${ }^{[8]}$.As Tsai, ShuChiao published Integration of Multimedia course ware into ESP Instruction for Technological Purposes in Higher Technical Education. 
D. Of the relationship between the research team of multimedia course ware from the perspective of interdisciplinary knowledge.

The authors supported the inclusion of different disciplines before the exchange, sharing the knowledge and experience of different disciplines, there by leading to the multimedia course ware for teaching them cross and integrity. Such as Alber published Multimedia: a management perspective. California: Wadsworth $^{[9]}$; Boyle published Design for multimedia learning. $U K^{[10]}$; Prentice-Hall published Chambers \& Whiting Communications of the ACM, 23(6), 332. ${ }^{[11]}$

\section{A SUMMARY OF DOMESTIC RESEARCH}

These are a total of 48159 related literatures with "the higher vocational colleges of multimedia course ware design status and strategic research" of full text research by virtue of the CNKI platform. In "the higher vocational colleges of multimedia course ware design status and strategic research" in the theme of search, there are a total of 39 related literatures. However, with its theme of doctoral and masters' thesis for search, there are only 14 relevant literature.

In the periodical literature, many scholars have applied the multimedia course ware to the specific subject and analyzed the advantages of multimedia application in the specific subject. First, the teaching forms of teachers are rich and varied so as to improve the efficiency of classroom teaching. Second, abstract and boring classroom content becomes more vivid to facilitate students' mastery of knowledge and understanding. Third, multimedia course ware for teachers and students learn more advanced knowledge that has updated fleetly. Such as the application of multimedia course ware in higher vocational English teaching by Zhou Beibei ${ }^{[12]}$

There is most literature of Flash software in the applied research of multimedia course ware in teaching. The analysis to flash software has the processing of text, graphic, images, animation, audio and other materials integrated capabilities based on the combination of specific disciplines to carry out specific courseware design and production of exploration. As Liu Bin and $\mathrm{Yi}$ Mian of production and application of multimedia course ware based on Flash ${ }^{[13]}$. From the characteristics of Flash software technology point of view; they compared and analyzed the traditional PPT course ware and Flash-based multimedia course ware, proposed targeted the design and production processes of Flash course ware, material collected and Flash course ware effect in terms of interactive teaching, teachers and students experience feedback and so on. In addition, it also emphasizes that teachers and students should work together to complete the course ware, so as to cultivate students' enthusiasm and initiative in classroom teaching. Deng Jianhui of Flash course ware in the application in the teaching of vocational schools ${ }^{[14]}$ from the basic course of computer network technology adhere to use the Flash course ware put on the network transmission of signal flow to give students directly demo out facilitate students intuitive understanding of the network data transmission. However, Ren Ningning of the secondary vocational schools to apply Flash course ware necessity ${ }^{[15]}$,through comparative analysis of the two kinds of multimedia teaching software of Flash and PPT analyses the advantages of PPT that are simple and learn, saving time and intuitively clear pictures of text. The disadvantages are the animation, difficult to arouse students' interactions and resonance. At the same time, the Flash can set text, pictures, audio and video materials for the development of strong interaction and other advantages, focused on the practical application of Flash teaching software in the design and production of course ware.

In the doctor's and master's thesis in the literature, many scholars analyze the present situation of multimedia course ware design from the hardware facilities of multimedia teaching, the teaching methods of multimedia course ware and traditional teaching ways compared to the previous and the ability of multimedia course ware. Such as Status Application of Multimedia Teaching in Higher Vocational Colleges and Strategies was published ${ }^{[16]}$ by Lin Lisong, and the research of strategy and countermeasures of modern educational technology in higher vocational colleges in Hunan ${ }^{[17]}$ was published by Meng Qinggang.

Some made a study from using multimedia course ware production related software combined with the specific course of multimedia courseware production steps and application from the specific professional courses. Such as $\mathrm{Li} \mathrm{Li}$ mechanical drawing course in the multimedia course ware animation technology research ${ }^{[18]}$ and Cui Yan the analysis of multimedia course ware production and use. ${ }^{[19]}$

Some studied from the classroom effect of discussion on teachers and students before the relation between interactive and multimedia course ware and from the perspective the study of interactive multimedia course ware design and application. Such as Di Yingjie design and production based on Flash of multimedia interactive course ware ${ }^{[20]}$ and Liu Weiwei design and application of multimedia interactive course ware. ${ }^{[21]}$

Others research the effect of multimedia in assisting other specific subjects. Articles from teachers and students of multimedia course ware attitudes and needs were analyzed and studied. Multimedia hardware facilities inadequate, teacher skills need to be improved. Student self-learning ability and other issues need to be strengthened and put forward countermeasures. Such as Investigation on the status of the multimedia language learning in higher vocational colleges ${ }^{[22]}$ published by Gao Xiang and Yang Yaojia of Study on the Multimedia-assisted Classroom of TCFL In School of Chinese Language and Literature BFSU.

Finally, "the status of multimedia course ware in gardening professional" as the theme to search in CNKI, searched a total of 48 papers, but associated with gardening only five papers.They are Wang Xiaohua,Ynag Baohang the application multimedia in the teaching of Horticultural(2005),Sun Shouru and Li Jing the application effect of multimedia course ware in Horticultural Plant Breeding. He Shan, Sheng Aiwu, Fang Xiaotian and Zhang Shijun application of multimedia technology in the teaching of Horticulture. He Yujing, Li He, Chen Xinchang and Zhang Hongmei the analysis of the role of multimedia course ware in teaching Horticulture and in 2003,application of multimedia technology in the teaching of Horticulture published by $\mathrm{Li}$ Hongyan in the Chinese contemporary education corpus. 
In addition, there are many scholars mainly from the production process of multimedia course ware for teaching design. Such as Wang Zhilong, Zhao Weiwei application of multimedia technology in teaching plant production ${ }^{[34]}$,the author suggests utilizing image-based teaching software, because it is simple, easy to use and learn. The production steps of making the multimedia teaching software PPT were detailed described which has important significance for improving the ability of teachers' multimedia software. However, there is a single application of multimedia teaching software and other issues. In the article by Jin Feng production and application of multimedia course ware for the Garden Plant Pests ${ }^{[25]}$.On a clear the foundation of Garden Plant Pests teaching objectives, key points and difficult points were chosen to find the suitable courseware development software and type of course ware--course ware for Classroom Demonstration, carefully collected text, graphic, video and other materials needed to produce course ware, course ware design adhere vivid and intuitive, easy to operate, innovative and scientific principles to produce the teaching multimedia course ware of Garden Plant Pests.

\section{CONCLUSION}

To sum up, in the study of existing literature, most scholars have researched a single kind of multimedia course ware as well as the characteristics of the methods of multimedia course ware design and production, the present situation and countermeasures of multimedia course ware in higher vocational colleges.

\section{REFERENCES}

[1] Babiker, Mohd. Elmagzoub A.For Effective Use of Multimedia in Education, Teachers Must Develop Their Own Educational Multimedia Applications.[J].Turkish Online Journal of Educational Technology TOJET, v14 n4 p62-68 Oct 2015.

[2] Pastore, Raymond; Ritzhaupt, Albert D.Using Time-Compression to Make Multimedia Learning More Efficient: Current Research and Practice[J]. Research and Practice to Improve Learning, v59 n2 p66-74 Mar 2015.

[3] Zydney, Janet Mannheimer; Hooper, Simon.Keeping Kids Safe from a Design Perspective: Ethical and Legal Guidelines for Designing a Video-Based App for Children[J].Research and Practice to Improve Learning, v59 n2 p40-46 Mar 2015.

[4] Osman, Salyani; Sahari, Noraidah; Zin.Development of Interactive Multimedia course ware (e-CRAFT) for Craft Education[J].Nor Azan Mat - Turkish Online Journal of Distance Education, 2012.
[5] Shiong, Kok Boon; Aris, Baharuddin; Ahmad, Maizah Hura; Bilal Ali, Mohamad; Harun, Jamalludin; Tasir,Learning "Goal Programming" Using an Interactive Multimedia course ware: Design Factors and Students' Preferences[J].Zaidatun - Journal of Educational Multimedia and Hypermedia, 2008.

[6] Chen, Jun; Wang, Zu-Yuan; Wu, Yuren.The Application of Flash in Web-Based Multimedia course ware Development[J].Interactive Technology and Smart Education, v6 n4 p268-273 2009.

[7] Hsiung, Liang-Yuan; Lai, Mu-Hui.[J].course ware on Color Management and Inspection Instruction.Journal of Educational Technology - TOJET, v12 n3 p91-106 Jul 2013.

[8] Tsai, Shu-Chiao.Integration of Multimedia course ware into ESP Instruction for Technological Purposes in Higher Technical Education[J].Educational Technology \& Society, v15 n2 p50-61 2012.

[9] Alber .Multimedia: a management perspective.California(1996).

[10] Boyle.Design for multimedia learning.UK(1997)

[11] Prentice-Hall; Chambers \& Whiting.Communications of the ACM," 23(6), 332

[12] Zhou Beibei the application of multimedia course ware in higher vocational English teaching [J]. EDUCATION ARTICLE (on Xunkan),2012,04:106+172.

[13] Liu Bin, Yi Mian production and application of multimedia course ware based on Flash.[J]. Technology Square, 2012,07: 102-105.

[14] Deng Jianhui Flash course ware in the application in the teaching of vocational schools.[J] occupation, 2009,15: 89.

[15] Ren Yuning the secondary vocational schools to apply Flash course ware necessity.[J] EDUCATION GUIDE (in Xunkan), 2014,01: 90-91.

[16] Lin liSong. Status Application of Multimedia Teaching in Higher Vocational Colleges and Strategies [D]. Shandong Normal University, 2007.

[17] Meng Qinggang Hthe research of strategy and countermeasures of modern educational technology in higher vocational colleges in Hunan[D]. Hunan Agricultural University, 2010.

[18] Li Li.mechanical drawing course in the multimedia course ware animation technology research [D]. Chang'an University, 2012.

[19] Cui Yan. the analysis of multimedia course ware production and use.[D]. Jilin University, 2010

[20] Di Yingjie. design and production based on Flash of multimedia interactive course ware .[D]. South China University of Technology, 2013.

[21] Liu.Weiwei design and application of multimedia interactive course ware[D].Shandong Normal University, 2008.

[22] Gao Xiang.Investigation on the status of the multimedia language learning in higher vocational colleges [D].Henan University, 2014.

[23] Yang Yaojia.Study on the Muitimedia-assisted Classroom of TCFL In School of Chinese Language and Literature BFSU.[D]. Beijing Foreign Studies University, 2014.

[24] Jin Feng.production and application of multimedia course ware for the Garden Plant Pests[J].Chinese education information, 2014,02: 64-66. 